\title{
Determination of Factors Affecting Bivalent (Type 1 and 3) Stability of Oral Poliomyelitis Vaccine
}

\author{
Sina Soleimani (PhD) \\ Department of Biobank, Razi Vaccine \\ and Serum Research Institute, \\ Agricultural Research Education and \\ Extension Organization (AREEO), \\ Karaj, Iran \\ Email: s.soleimani@rvsri.ac.ir \\ Tel: $+98-2634570038$ \\ Address: Department of Biobank, \\ Razi Vaccine \& Serum Research \\ Institute, Agricultural Research \\ Education and Extension Organization \\ (AREEO), Karaj, Iran \\ Received: 04 Mar 2019 \\ Revised: 01 Jun 2019 \\ Accepted: 19 Jun 2019

\section{(c) (i) (8)} \\ This work is licensed under a Creative \\ Commons Attribution 4.0 License.
}

\author{
ABSTRACT \\ Background and Objectives: In recent years, due to the eradication of type 2 \\ poliovirus, a bivalent vaccine containing types 1 and 3 is used in Iran. Since it is a \\ highly thermolabile vaccine, it should be stored at a recommended temperature. Since cold \\ chain may not be applied in Iran's tropical weather conditions, potency of the vaccine may \\ be subjected to change. Therefore, we evaluated the effective factors on the potency of this \\ vaccine.
}

Methods: We evaluated stability of a bivalent oral poliovirus vaccine produced by Razi Institute of Iran to ensure consistency of virus at different temperatures $(-20,2-8,22-25$ and $\left.35-37^{\circ} \mathrm{C}\right)$, time intervals and freeze/thaw cycles. Three consecutive batches produced during full-scale production were randomly sampled.

Results: At $-20{ }^{\circ} \mathrm{C}$, there was no change in vaccine vial monitor (VVM). The potency of the samples exposed to 2-8 ' $\mathrm{C}$ for 60 days and to $22-25{ }^{\circ} \mathrm{C}$ for five days met the specification. The mean potency of the samples was 6.17, 6.00, 5.83, 5.75 and $5.54(\log$ C(IID50/dose) after 10, 20, 30, 40 and 50 freeze/thaw cycles, respectively. In addition, the mean degradation of VVM was 0, 23.33, 60 and $100 \%$ for samples exposed to -20, 2-8, 22-25 and 35-37 $\mathrm{\circ}$, respectively.

Conclusion: The results indicate the effects of environmental factors on the potency of the vaccines and the correlation between the VVM grade, color change and the vaccine potency for programming vaccine distribution networks at different transit levels. Based on the results of our study, the best temperature for maintenance and transportation of bivalent oral poliovirus vaccine is $-20{ }^{\circ} \mathrm{C}$. Furthermore, freeze/thaw cycles lower the potency of the vaccine and change the VVM grade significantly.

Keywords: Poliovirus vaccine, Refrigeration, Temperature, Freezing, Vaccine potency, Iran, Immunization programs, Vaccination, Protein stability

This paper should be cited as: Soleimani S [Determination of Factors Affecting Bivalent (Type 1 and 3 ) Stability of Oral Poliomyelitis Vaccine]. mljgoums. 2020; 14(1): 36-43 


\section{INTRODUCTION}

Due to risk of rapid potency loss, vaccines should be kept under recommended temperatures (1). Because of lack of ice packs, freezer and efficient transport subtractions, the cold chain under field situations is often challenging (2). Therefore, vaccine vial monitor (VVM), a heat and time-sensitive sticker, is glued to WHO-prequalified vaccines based on polymerization technology (3). When exposed to a high temperature, the potency of vaccines will drop and the VVM inner square changes to a dark color. When the color of the inner square merges with the outer circle, the VVM endpoint is reached and the vaccine should be discarded. This indicates whether the vaccine remains sufficiently potent for use, even when the cold chain is not trusted. Studies have determined a correlation between the VVM grade and the vaccine potency (4).

Currently, the oral poliovirus vaccine (OPV) is the best choice to prevent polio outbreaks and transmission of wild viruses (5). After eradication of wild-type 2 poliovirus, some countries including Iran introduced the bivalent OPV (bOPV) such as type 1 and type 3 polioviruses (6). This vaccine is highly thermolabile (inactivated at $55{ }^{\circ} \mathrm{C}$ for 30 minutes) and needs VVM2, with an endpoint at $37{ }^{\circ} \mathrm{C}$ for two days or more (7) and is stable for two years at $-20{ }^{\circ} \mathrm{C}(8)$. Because kinetics is used for vaccine degradation rate estimation following inappropriate storage and transportation conditions (9), the samples in this study were stored at 2-8, 22-25 and 35-37 ${ }^{\circ} \mathrm{C}$. The overall objective of this study is to measure and monitor the potency of vaccines in different storage conditions and to evaluate the relationship between OPV potency, VVM and heat exposure.

\section{MATERIALS AND METHODS}

From three consecutive batches of the bOPV, 300 tubes were randomly sampled. Then, the samples were stored at -20, 2-8, 22-25 and 35$37{ }^{\circ} \mathrm{C}$ (temperature of tropical regions and most parts of Iran). Second series of samples were exposed to $10,20,30,40$ and 50 freeze/thaw cycles. The validity of these temperatures was checked by observation two times a day and rechecked by recording the temperature every hour by a cool vision system.

After each vaccine challenge, for detection any contamination, each sample was cultured in brain heart infusion agar, tryptic soy broth, thioglycolate broth and blood agar. For mycoplasma detection, the samples were cultured and subcultured in pleuropneumonialike organism broth and agar (selective medium for mycoplasma cultivation and maintenance), respectively (10).

Physicochemical tests including stabilizer content $\left(\mathrm{MgCl}_{2}\right)$, airtightness, appearance, labeling, $\mathrm{pH}$ and extractable volume were done at the beginning and after each stress situation. When testing the appearance, consistency, color, transparency and any visible particle were considered. Stability of label and tube airtightness were inspected. The $\mathrm{MgCl}_{2}$ content was tested by complexometric titration assay, and $\mathrm{pH}$ of the samples was determined by assessing the hydrogen ion content. Finally, volume of each vial was estimated by drop count (8).

All samples were tested for potency after exposure to freeze/thaw cycles and temperatures of $-20,2-8,22-25$ and $35-37{ }^{\circ} \mathrm{C}$ for $2,4,7,10,14,21,30$ and 60 days (11): After preparation of the HeLa cells (ATCC CCL-2) (12), the vaccine was diluted and added into a microtiter plate (Nunc). Then, a cell suspension $\left(2 \times 10^{5}\right.$ cells $\left./ \mathrm{ml}\right)$ was added to the plate. After 4-7 days, the cells were observed for cytopathic effects. The vaccines' CCID50 was determined by estimating the $50 \%$ endpoint by the Spearman-Karber method per dose (13). Later, the geometric mean titer was determined in triplicate. The titer of the bivalent vaccine must be more than $10^{6} \mathrm{CCID50/dose}$ as the minimal protective titer according to the WHO requirements (14). The VVM was classified as follows: $\begin{array}{lllllllllll}0 \% & 10 \% & 20 \% & 30 \% & 40 \% & 50 \% & 60 \% & 70 \% & 80 \% & 90 \% & 100 \%\end{array}$

\section{(2)}

In parallel to each potency test, the VVM of the vials in different conditions was evaluated and classified at baseline and after each vaccine challenge based on the above VVM grading.

For validation of the tests, system suitability was controlled and potency of a vaccine standard was determined in parallel to test vaccines. The difference was $10^{0.36}$ CCID50/dose (less than $10^{0.5}$ on the base of requirements) verifying the assay's validity (15).

The least squares regression analysis and a 
linear regression model were used for analysis of vaccine stress test data.

\section{RESULTS}

All polio vaccine samples were free from fungal, bacterial (aerobic and anaerobic) and mycoplasma contamination during the study process. The vaccine samples met the specification after each physicochemical test and vaccine challenge condition (Table 1 ).

Table 2 shows the results of the potency test in different conditions. At $-20{ }^{\circ} \mathrm{C}$, there was no reduction in the potency in the test periods and there was no change in VVM (VVM grade was zero). The potency of the samples exposed to $2-8{ }^{\circ} \mathrm{C}$ for 60 days met the specification. At 22-25 ${ }^{\circ} \mathrm{C}$, the samples met the specification until five days after which the potency of the vaccines decreased to 5.05, 5.05 and $4.93(\log$ CCID50/dose) for each batch, respectively. The VVM minimum grade of the samples, 60 days after exposure to $2-8{ }^{\circ} \mathrm{C}$ and $22-25{ }^{\circ} \mathrm{C}$ was $40 \%$ and $70 \%$, respectively. Exposure to $35-37{ }^{\circ} \mathrm{C}$ for two days reduced the potency and the potency of three batches reached the lowest level $(<4.00)$ after 21 days. As shown in table 2, the VVM grade was $100 \%, 21$ days after exposure to 35 $37{ }^{\circ} \mathrm{C}$. Figures 1 and 2 show the linear regression fit of data obtained from table 2.

The mean potency of the samples was $6.17, \quad 6.00, \quad 5.83, \quad 5.75$ and $5.54 \quad(\log$ CCID50/dose) after 10, 20, 30, 40 and 50 freeze/thaw cycles, respectively. The linear regression fit of data from table 3 is shown in figure 3 . The mean degradation of VVM was $0,23.33,60$ and $100 \%$ for samples exposed to $-20,2-8,22-25$ and $35-37{ }^{\circ} \mathrm{C}$, respectively (Table 2). The results of vaccines VVM gradation in different freeze/thaw cycles are shown in table 3 .

Table 1- Physicochemical tests of polio vaccines in long term stability evaluation

\begin{tabular}{|c|c|c|c|c|c|c|c|c|c|c|c|c|}
\hline \multirow{3}{*}{$\begin{array}{c}\text { Sample } \\
\text { A }\end{array}$} & \multirow{3}{*}{$\begin{array}{c}\text { Test } \\
\mathrm{MgCl}_{2} \text { Content }\end{array}$} & \multirow{3}{*}{$\begin{array}{l}\text { Specification } \\
1.00 \mathrm{M} \pm 0.1\end{array}$} & \multicolumn{10}{|c|}{ Results* } \\
\hline & & & \multicolumn{2}{|c|}{$-20^{\circ} \mathrm{C}$} & \multicolumn{2}{|c|}{$2-8^{\circ} \mathrm{C}$} & \multicolumn{2}{|c|}{$22-25^{\circ} \mathrm{C}$} & \multicolumn{2}{|c|}{$35-37^{\circ} \mathrm{C}$} & \multicolumn{2}{|c|}{ Freeze/thaw cycles } \\
\hline & & & $\begin{array}{c}\text { Beginning } \\
0.93\end{array}$ & $\begin{array}{l}\text { End } \\
\mathbf{0 . 9 3}\end{array}$ & $\begin{array}{l}\text { Beginning } \\
0.92\end{array}$ & $\begin{array}{l}\text { End } \\
0.93\end{array}$ & $\begin{array}{l}\text { Beginning } \\
0.92\end{array}$ & $\begin{array}{l}\text { End } \\
0.91\end{array}$ & $\begin{array}{l}\text { Beginning } \\
0.93\end{array}$ & $\begin{array}{l}\text { End } \\
0.90\end{array}$ & $\begin{array}{l}\text { Beginning } \\
\quad 0.92\end{array}$ & $\begin{array}{l}\text { End } \\
0.90\end{array}$ \\
\hline & pH & $6.50-7.50$ & 7.13 & 7.15 & 7.13 & 7.15 & 7.14 & 7.18 & 7.14 & 7.21 & 7.13 & 7.18 \\
\hline & $\begin{array}{c}\text { Extractable } \\
\text { volume }\end{array}$ & $\begin{array}{l}\text { At least } 30 \\
\text { drops/tube }\end{array}$ & 30 & 30 & 31 & 31 & 30 & 30 & 30 & 29 & 30 & 30 \\
\hline & $\begin{array}{l}\text { Sterility and } \\
\text { Mycoplasma }\end{array}$ & $\begin{array}{c}\text { To be free } \\
\text { from fungal } \\
\text { and bacterial } \\
\text { agents and } \\
\text { mycoplasma }\end{array}$ & Approved & Approved & Approved & Approved & Approved & Approved & Approved & Approved & Approved & Approved \\
\hline \multirow[t]{4}{*}{ B } & $\mathrm{MgCl}_{2}$ content & $1.00 \mathrm{M} \pm \mathbf{0 . 1}$ & 0.93 & 0.92 & 0.92 & 0.92 & 0.92 & 0.92 & 0.92 & 0.93 & 0.92 & 0.92 \\
\hline & pH & $6.50-7.50$ & 7.12 & 7.15 & 7.13 & 7.15 & 7.16 & 7.18 & 7.14 & 7.14 & 7.15 & 7.12 \\
\hline & $\begin{array}{c}\text { Extractable } \\
\text { volume }\end{array}$ & $\begin{array}{l}\text { At least } 30 \\
\text { drops/tube }\end{array}$ & 30 & 30 & 30 & 30 & 30 & 30 & 30 & 29 & 30 & 30 \\
\hline & $\begin{array}{l}\text { Sterility and } \\
\text { Mycoplasma }\end{array}$ & $\begin{array}{l}\text { To be free } \\
\text { from fungal } \\
\text { and bacterial } \\
\text { agents and } \\
\text { mycoplasma }\end{array}$ & Approved & Approved & Approved & Approved & Approved & Approved & Approved & Approved & Approved & Approved \\
\hline \multirow[t]{4}{*}{ C } & $\mathrm{MgCl}_{2}$ content & $1.00 \mathrm{M} \pm 0.1$ & 0.92 & 0.92 & 0.92 & 0.93 & 0.92 & 0.92 & 0.91 & 0.92 & 0.90 & 0.90 \\
\hline & pH & $6.50-7.50$ & 7.13 & 7.15 & 7.13 & 7.15 & 7.14 & 7.18 & 7.14 & 7.21 & 7.13 & 7.18 \\
\hline & $\begin{array}{c}\text { Extractable } \\
\text { volume }\end{array}$ & $\begin{array}{l}\text { At least } 30 \\
\text { drops/tube }\end{array}$ & 30 & 30 & 30 & 30 & 30 & 30 & 30 & 30 & 30 & 30 \\
\hline & $\begin{array}{l}\text { Sterility and } \\
\text { Mycoplasma }\end{array}$ & $\begin{array}{l}\text { To be free } \\
\text { from fungal } \\
\text { and bacterial } \\
\text { agents and } \\
\text { mycoplasma }\end{array}$ & Approved & Approved & Approved & Approved & Approved & Approved & Approved & Approved & Approved & Approved \\
\hline
\end{tabular}


Table 2- Potency (log CCID50/dose) and VVM grade of polio vaccine exposed to heat

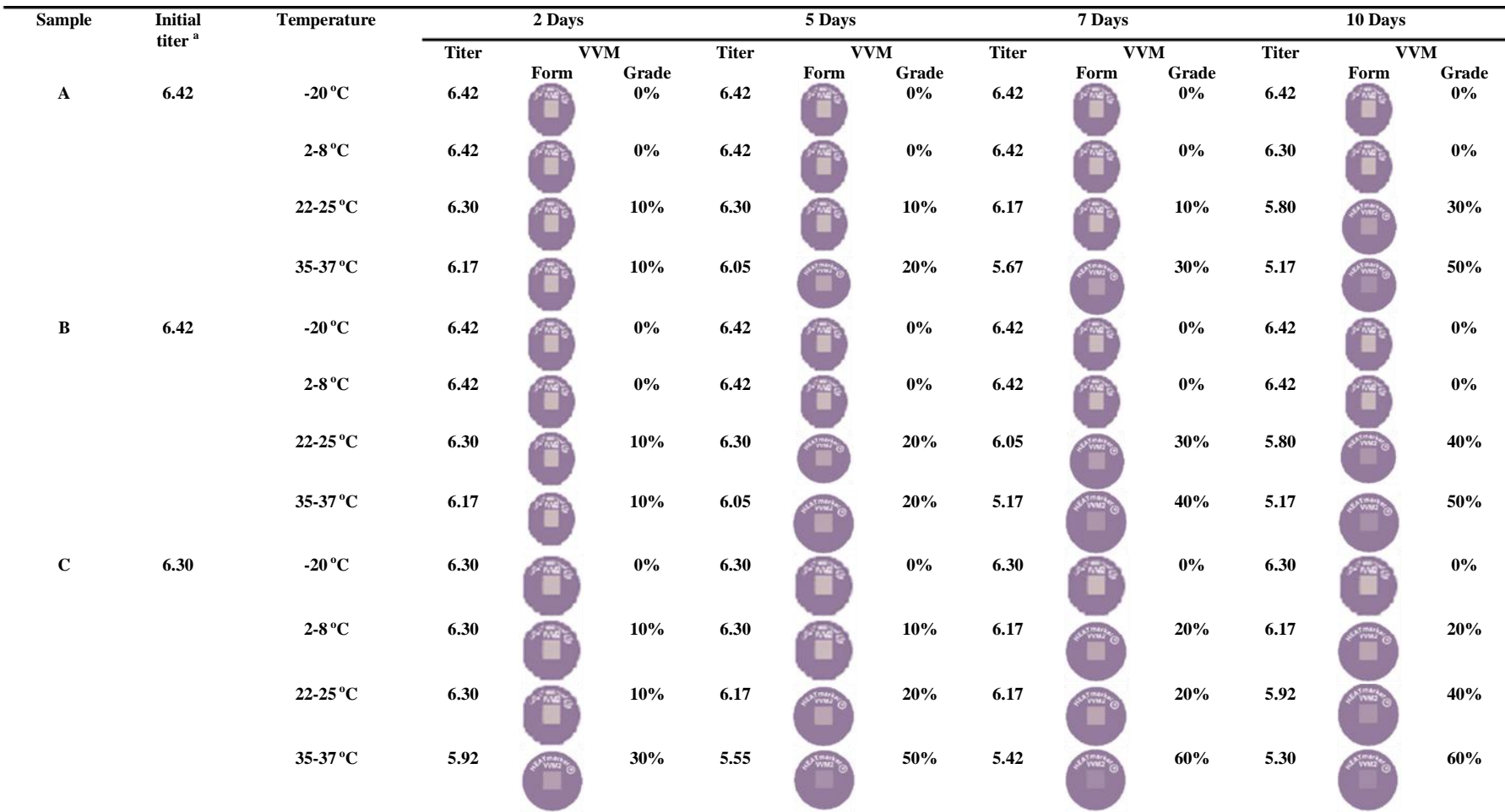

Table 2- Potency (log CCID50/dose) and VVM grade of polio vaccine exposed to heat (Continued)

\begin{tabular}{|c|c|c|c|c|c|c|c|c|c|c|c|}
\hline \multirow[t]{2}{*}{ Sample } & \multirow{2}{*}{$\begin{array}{l}\text { Initial } \\
\text { titer }^{\text {a }}\end{array}$} & \multirow[t]{2}{*}{ Temperature } & \multicolumn{2}{|r|}{14 Days } & \multicolumn{2}{|r|}{21 Days } & \multicolumn{2}{|r|}{30 Days } & \multicolumn{3}{|c|}{60 Days } \\
\hline & & & Titer & VVM & Titer & VVM & Titer & VVM & \multirow[t]{2}{*}{ Titer } & \multicolumn{2}{|c|}{ VVM } \\
\hline \multirow[t]{4}{*}{ A } & 6.42 & $-20^{\circ} \mathrm{C}$ & 6.42 & $\begin{array}{cc}\text { Form } & \text { Grade } \\
& \mathbf{0} \%\end{array}$ & 6.42 & Form $\quad \begin{array}{c}\text { Grade } \\
0 \%\end{array}$ & 6.42 & Form $\quad$ Grade & & Form & $\begin{array}{l}\text { Grade } \\
\mathbf{0 \%}\end{array}$ \\
\hline & & $2-8^{\circ} \mathrm{C}$ & 6.30 & $10 \%$ & 6.30 & $10 \%$ & 6.17 & $10 \%$ & 6.17 & & $10 \%$ \\
\hline & & $22-25^{\circ} \mathrm{C}$ & 5.80 & $30 \%$ & 5.67 & $30 \%$ & 5.17 & $40 \%$ & 5.05 & & $\mathbf{5 0} \%$ \\
\hline & & $35-37^{\circ} \mathrm{C}$ & 4.67 & $80 \%$ & 4.12 & $100 \%$ & $<4.00$ & $100 \%$ & $<4.00$ & & $100 \%$ \\
\hline \multirow[t]{4}{*}{ B } & 6.42 & $-20^{\circ} \mathrm{C}$ & 6.42 & $0 \%$ & 6.42 & $0 \%$ & 6.42 & $0 \%$ & 6.42 & & $0 \%$ \\
\hline & & $2-8^{\circ} \mathrm{C}$ & 6.17 & $10 \%$ & 6.17 & $10 \%$ & 6.17 & $20 \%$ & 6.05 & & $20 \%$ \\
\hline & & $22-25^{\circ} \mathrm{C}$ & 5.80 & $40 \%$ & 5.67 & $40 \%$ & 5.05 & $60 \%$ & 5.05 & & $60 \%$ \\
\hline & & $35-37^{\circ} \mathrm{C}$ & 4.12 & $\mathbf{9 0 \%}$ & $<4.00$ & $100 \%$ & $<4.00$ & $100 \%$ & $<4.00$ & & $100 \%$ \\
\hline \multirow[t]{4}{*}{ C } & 6.30 & $-20^{\circ} \mathrm{C}$ & 6.30 & $0 \%$ & 6.30 & $0 \%$ & 6.30 & $0 \%$ & 6.30 & & $0 \%$ \\
\hline & & $2-8^{\circ} \mathrm{C}$ & 6.05 & $30 \%$ & 5.80 & $30 \%$ & 5.67 & $40 \%$ & 5.55 & & $40 \%$ \\
\hline & & $22-25^{\circ} \mathrm{C}$ & 5.80 & $40 \%$ & 5.55 & $\mathbf{5 0 \%}$ & 5.05 & $60 \%$ & 4.93 & & $70 \%$ \\
\hline & & $35-37^{\circ} \mathrm{C}$ & 5.05 & $70 \%$ & $<4.00$ & $100 \%$ & $<4.00$ & $100 \%$ & $<4.00$ & & $100 \%$ \\
\hline
\end{tabular}

Table 3- Effect of freeze/thaw cycles on potency (log CCID50/dose) and VVM grade of polio vaccine

\begin{tabular}{|c|c|c|c|c|c|c|c|c|c|c|c|c|c|c|c|c|}
\hline \multirow[t]{3}{*}{ Sample } & \multirow{2}{*}{$\begin{array}{l}\text { Initial } \\
\text { titer }^{a}\end{array}$} & \multicolumn{3}{|c|}{10 Cycles } & \multicolumn{3}{|c|}{20 Cycles } & \multicolumn{3}{|c|}{30 Cycles } & \multicolumn{3}{|c|}{40 Cycles } & \multicolumn{3}{|c|}{50 Cycles } \\
\hline & & Titer & & & Titer & & & Titer & & & Titer & & & Titer & & \\
\hline & 6.42 & 6.17 & Form & $\begin{array}{c}\text { Grade } \\
0 \%\end{array}$ & 5.92 & Form & $\begin{array}{c}\text { Grade } \\
20 \%\end{array}$ & 5.92 & Form & $\begin{array}{c}\text { Grade } \\
\mathbf{3 0} \%\end{array}$ & 5.80 & Form & $\begin{array}{c}\text { Grade } \\
40 \%\end{array}$ & 5.55 & Form & $\begin{array}{c}\text { Grade } \\
\mathbf{4 0 \%}\end{array}$ \\
\hline B & 6.42 & 6.42 & & $0 \%$ & 6.17 & & $10 \%$ & 5.92 & & $20 \%$ & 5.92 & & $20 \%$ & 5.67 & & $30 \%$ \\
\hline $\mathrm{C}$ & 6.30 & 6.05 & & $10 \%$ & 5.92 & & $20 \%$ & 5.67 & & $40 \%$ & 5.55 & & $\mathbf{5 0 \%}$ & 5.42 & & $\mathbf{5 0 \%}$ \\
\hline
\end{tabular}




\section{DISCUSSION}

Vaccine stability is critical for successfully delivery of global immunization programs (9).

Several factors affect vaccines stability such as preservatives, lyophilization process, vials or tubes, monitoring process, vaccine production, maintenance equipment, transportation and cold chain (16).

Nowadays, a majority of vaccination failures results from thermal instability (17). The most important step to vaccine stability monitoring is an analytical method adoption for determination of specific vaccine ability as the "potency test", which is calculated by appropriate laboratory tests. Long-term maintenance, transit to health centers and the period immediately prior to injection might reduce vaccine potency (18). Preserving the vaccine potency by cold chain and maintenance during transportation seem to be more critical for developing countries, especially the tropical countries such as Iran where the cold chain is usually not available. A successful immunization program requires vaccines to be stored and transported properly while being under continuous temperature monitoring that helps detection of cold chain failure $(19,20)$.

Figure 1- Linear regression fit of data for mean virus titer $(\log$ CCID50/dose) of bOPV samples at different temperatures and time intervals.

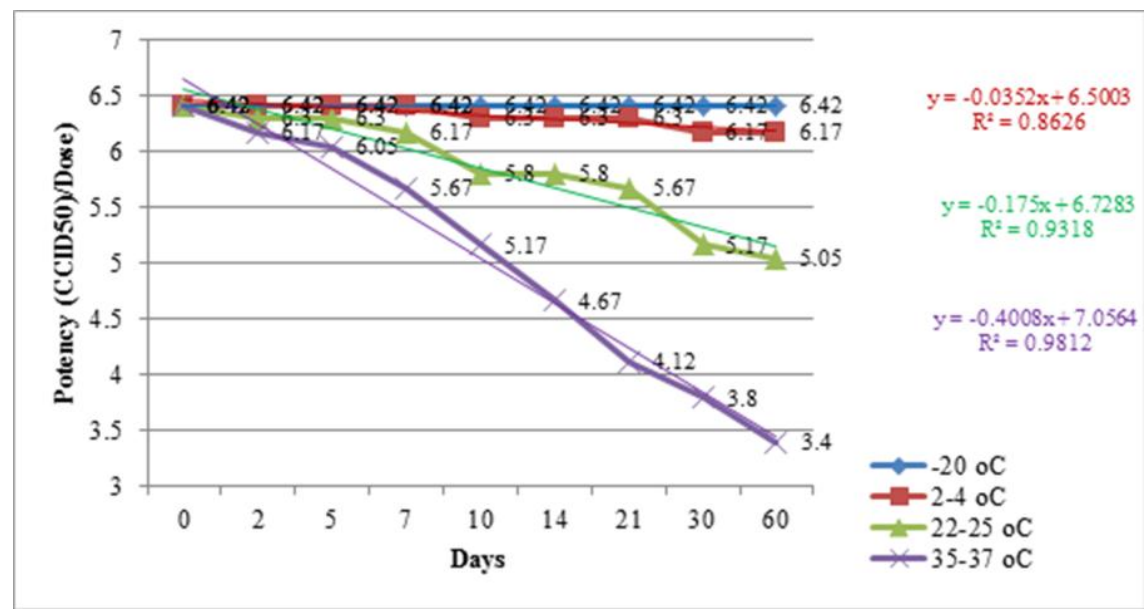

Figure 2 -Linear regression fit of data for bOPV VVM status at different temperatures and time

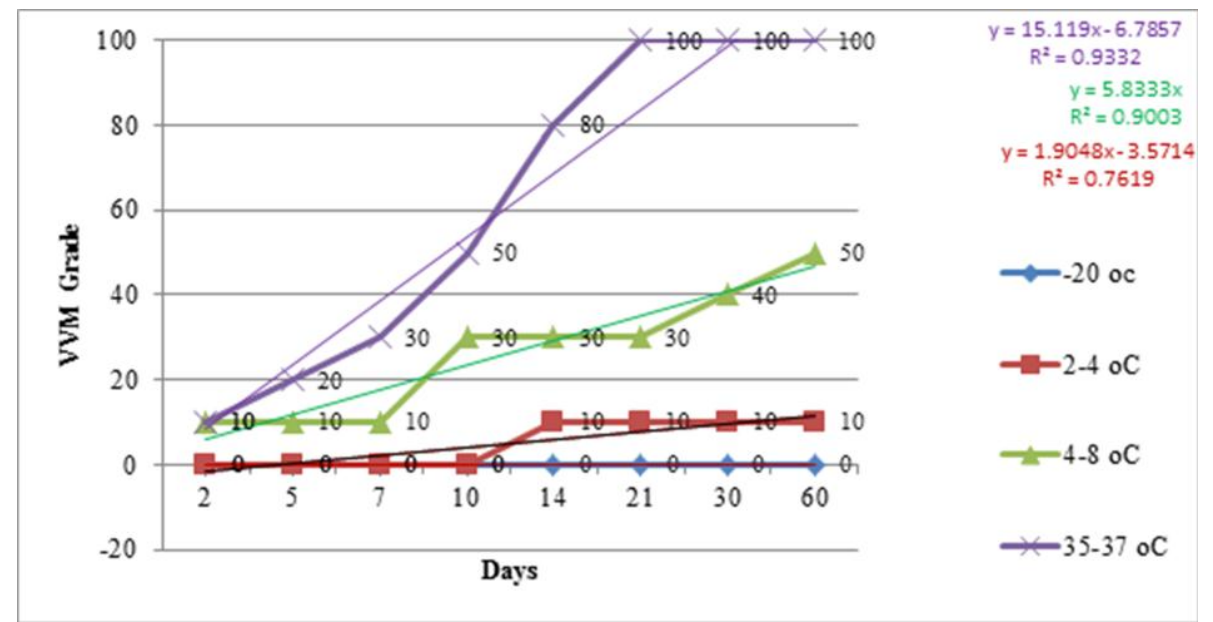


Figure 3- Linear regression fit of data for correlation of freeze/thaw cycles and VVM grade

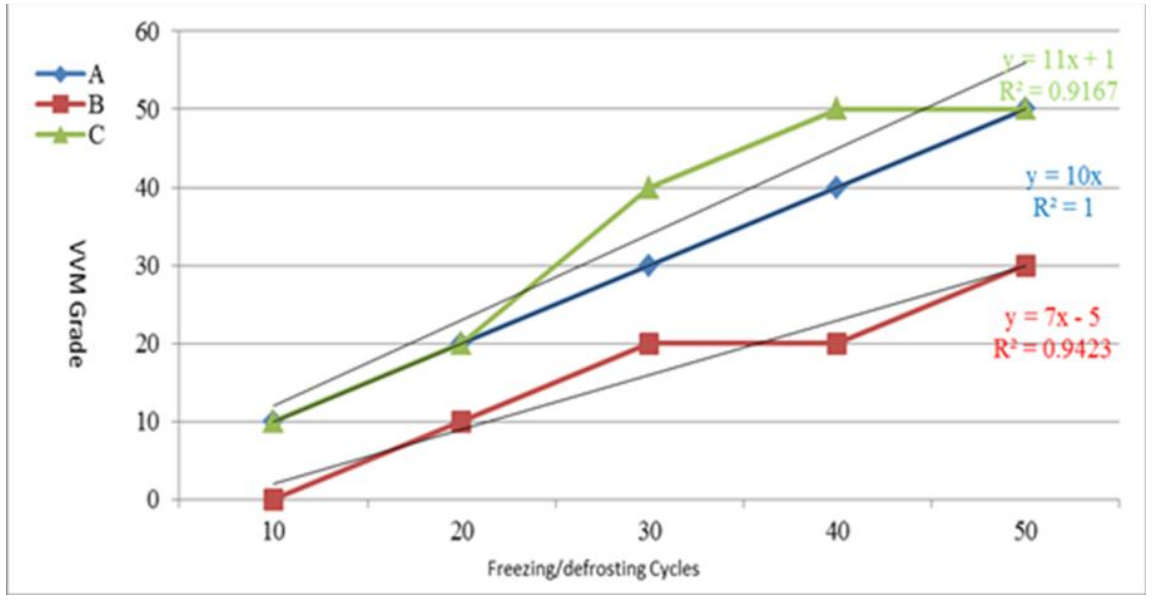

Polioviruses are resistant to some common inactivating factors including ethanol, ether, chloroform and non-ionic detergents but sensitive to ultraviolet light, heat $\left(55^{\circ} \mathrm{C}\right)$, chlorine and formaldehyde (21).

From 17 April until 1 May 2016, the first stage of OPV cessation was successfully implemented in more than 150 countries and territories: a globally synchronized "switch" from the trivalent OPV to bOPV, which contains poliovirus type 1 and 3 (22).

Thermostability of polio vaccines has been the subject of many studies over the past few decades, particularly in polio-endemic countries $(8,23-26)$. According to biophysical studies, polioviruses can be inactivated by moderate heat exposure $\left(42-45^{\circ} \mathrm{C}\right)(13,27)$. At $-20{ }^{\circ} \mathrm{C}$, the potency of this vaccine retains over a long period $(8,28)$, but at $3-5{ }^{\circ} \mathrm{C}$, the stability of the vaccine is less than six months (29). Magnesium chloride is used as a stabilizer in OPV (18) with no significant loss of potency for as long as nine freeze/thaw cycles (30). Some researches employed VVM to specify the effects of OPV heat exposure. In a study by Samant et al., heat exposure in the last stage of the vaccine cold chain damaged $9 \%$ of the vaccines in health centers of India. The authors reported ice packs as well as storage and transportation temperature as the most important factors in temperature-induced OPV damage (24). In a study in a remote area of Mali, storing OPV without the cold chain during an OPV vaccination campaign was proven acceptable as long as the vaccine does not reach the endpoint (based on the VVM reading) (25). A study in Chad reported similar results regarding OPV storage (26) .
We designed this study based on VVM grade scoring for vaccine vials and testing of the vaccine for total OPV potency according to the standard WHO protocol. The results of the bOPV potency test in recommended temperature showed that all samples had a titer of more than $10^{6.15}$ CCID50/dose (WHO bivalent vaccine specification, as the total titer is fixed in bOPV, composite titer estimation is sufficient to assess the thermal stability) and no change was made to the VVM for 60 days. The same result was reported in previous studies until 24 months (8). Storage in refrigerator $\left(2-8{ }^{\circ} \mathrm{C}\right)$ decreased the potency but the VVM grade was still somewhat favorable. One week storage at room temperature (22-25 $\left.{ }^{\circ} \mathrm{C}\right)$ decreased the potency of the samples to below $10^{6}$ (CCID50/dose) and changed the VVM grade. After 60 days, the potency reached $10^{5}$ and the VVM grade was changed to $70 \%$. In incubator $\left(35-37{ }^{\circ} \mathrm{C}\right)$, the specification of the vaccine was not acceptable after five days. According to our findings, this vaccine is stable for 60 days, $<10$ days and $<5$ days at 2-8, 22-25 and $33-37^{\circ} \mathrm{C}$, respectively. When evaluating the effect of freeze/thaw cycles on the vaccine, we found that 20 cycles decreased the vaccine's potency below the specification and altered the VVM to $20 \%$. In addition, 40 freeze/thaw cycles decreased the potency to a very low level and the VVM grade reached $50 \%$ so that the vaccine was no longer usable. The results showed that all tested bOPV vaccines met the WHO specifications at the beginning and at the end of the study period, which indicates the favorable production conditions at the Razi Institute. 


\section{CONCLUSION}

We revealed the stability of three consecutive batches of bOPV vaccines at different test conditions. The results indicated the effects of environmental factors on the potency of the vaccines and the correlation between the VVM grade, color change and vaccine potency for programming at vaccine injection sites. Based on the results of our study, the followings should be considered by vaccine program managers:

1 . The bOPV is a highly thermolabile vaccine that requires cold chain for storage and transport.

2. The best temperature for maintenance and transportation of bOPV is $-20{ }^{\circ} \mathrm{C}$.

3. Duration of exposure to high temperatures is very important.

\section{REFERENCES}

1. Martin Ndinakie Yakum JA, Fida Ramsina Pélagie, Ebile Akoh Walter and Pierre Watcho. Factors associated with the exposure of vaccines to adverse temperature conditions: the case of North West region, Cameroon. BMC Res Notes 2015;8(1):277.

2. Samant Y LH, Parker D, Block L, Tomar GS, Stein B. Evaluation of the cold-chain for oral polio vaccine in a rural district of India. Public Health Reports 2007; 122:112e21.

3. JohnLloyd a. The origins of the vaccine cold chain and a glimpse of the future. 2017;35(17):2115-20.

4. Deshpande DP, Nadkarni S.S. . Field performance of VVM is evaluated in India. World Health Organization, Polio Lab Network Quarterly Update. 2004:2-3.

5. Heleen Kraan PvH, Gideon Kersten, and Jean-Pierre Amorij. Development of Thermostable Lyophilized Inactivated Polio Vaccine. Pharm Res. 2014;31(10):2618-29.

6. Thapa SBAHAOEDJNA. The Switch From Trivalent to Bivalent Oral Poliovirus Vaccine in the South-East Asia Region. The Journal of Infectious Diseases. 2017;216(1):S94-S100.

7. Ashutosh Shrivastava NG, Pramod Upadhyay, and Jacob Puliyel. Caution needed in using oral polio vaccine beyond the cold chain: Vaccine vial monitors may be unreliable at high temperatures. Indian $\mathrm{J}$ Med Res. 2012;135(4):520-2.

8. Soleimani S, Bordbar, N. . Stability Study of Razi Trivalent and Monovalent Oral Poliomyelitis Vaccine. Archives of Razi Institute 2012;67(1):27-34.

9. D C. Accurate prediction of vaccine stability under real storage conditions and during temperature excursions. Eur J Pharm Biopharm. 2018;125:76-84.

10. Soleimani S. Stability Study of Measles AIK-C Strain, Mumps RS-12 Strain.

and Rubella Takahashi Strain in MMR Vaccine. Archives of Razi Institute. 2016;71(1):21-8.
4. Freeze/thaw cycles lower the potency of the vaccine and change the VVM grade significantly.

\section{ACKNOWLEDGMENTS}

This study received financial support by the Razi Vaccine and Serum Research Institute (research projects No: 2-18-1886034). The authors would like to thank the staff of human viral vaccine production, viral vaccine quality control and biobank departments and the Razi Vaccine and Serum Research Institute for their cooperation.

\section{CONFLICT OF INTEREST}

The authors declare that there is no conflict of interest.

11. WHO. Manual of laboratory methods for testing the potency of final vaccines used in the WHO expanded program on immunization. Potency. Geneva: World Health Organization. Vaccine Supply and Quality Unit; 1995. p. 67-74.

12. Freshny RI. Culture of Animal cells, A manual of basic technique and specialized applications. sixth, editor. Hoboken, New Jersey: Wiley- Black well; 2010. $732 \mathrm{p}$.

13. Muhammad T, Baba, S.S., Zaria, L.T., Yuguda, AD., Thilza, IB., . Determination Of thermal stability of oral polio vaccine $(\mathrm{Opv})$ at different temperature under laboratory conditions. Stem cell 2010;1(1):69-73.

14. WHO. WHO expert committee on biological standardization, Recommendation for the production and control of poliomyelitis vaccine (oral). WHO expert commitee on biological standardization. ; 2002. p. 56-8.

15. ICH. Validation of analytical procedures: Text and methodology. Q2(R1) International conference on harmonization of technical requiremnets for registration of pharmaceuticals for human use. ; 2005.

16. Ashvin Ashok MB, Yann LeTallec. Improving cold chain systems: Challenges and solutions. vaccine. 2017;35:2217-23.

17. Middaugh DTBSJMWR. Thermal Stability of Vaccines. Journal of Pharmaceutical Sciences. 2003;92(2):218-31.

18. Ozan S. Kumru SBJ, Dawn E. Smith , C. Russell Middaugh , Ted Prusik, David B. Volkin. . Vaccine instability in the cold chain: Mechanisms, analysis and formulation strategies. Biologicals 2014;42:237e59.

19. Jain R, Sahu, A.K., Tewari, S., Malik, N., Singh, S., Khare, S., Bhatia, R. . Cold chain monitoring of OPV at transit levels in India: correlation of VVM and potency status. Biologicals 2003;31:237-44.

20. Gradon JD, Lutwick, L.I. . Maintaining and enhancing vaccine immunogenecity

Infectious Disease Clinics of North America 1999;13(1):39-60. 
21. Ananda S Bandyopadhyay JG, Katherine Seib \& Walter A Orenstein. Polio vaccination: past, present and future. Future Microbiol. 2015;10(5):791-808.

22. Weldon EBBCBSWFWARICSLJAWMEAMAMSOWC. Intestinal Immune Responses to Type 2 Oral Polio Vaccine (OPV) Challenge in Infants Previously Immunized With Bivalent OPV and Either High-Dose or Standard Inactivated Polio Vaccine. The Journal of Infectious Diseases. 2018;217(3):371-80.

23. Acu FD AA, Esan JS, Odusanya OG. Live viral vaccine potency: an index for assessing the cold chain system. Public Health Rep. 1996;110:325e30.

24. Samant Y, Lanjewar, H., Parker, D., Block, L., Tomar, G.S., Stein, B. . Evaluation of the cold-chain for oral polio vaccine in a rural district of India. Public Health Rep 2007;122(1):112-21.

25. Halm A YeI, Kamissoko M, Keïta T, Modjirom N, Zipursky S, et al. Using oral polio vaccine beyond the cold chain: a feasibility study conducted during the national immunization campaign in Mali. Vaccine 2010;28:3467e72.
26. Zipursky S BL, Cheikh DO, Fournier-Caruana J, Hamid D, Janssen M, et al. Assessing the potency of oral polio vaccine kept outside of the cold chain during a national immunization campaign in Chad. Vaccine 2011;29(5652e6).

27. Yuan Wang D, Ing Yang, R., Chen Yang, Y., Yen Yeh, Sh., Ling Chen, T., Fang Cheng, H., Tian Hsieh, J., Polin, C. . The Relationship between the Cold Chain System and Vaccine Potency in Taiwan: (II) Oral Polio Vaccine. Journal of Food and Drug Analysis $2000 ; 8(8): 17-23$.

28. Chand T, Sahu, A. K., Saha, K., Meena, j., Singh, S. . Stability of oral polio vaccine at different temperatures and its correlation with vaccine vial monitors. Current science 2008;94(2):172-5.

29. Sokhey J, Gupta, C.K., Sharma, B., Singh, H. Stability of oral polio vaccine at different temperature. Vaccine 1988;6(6):12-3.

30. Petersen I, Von Magnus, H.P., Pipkin, P.A. . Characterisation of L Cells Expressing the Human Poliovirus Receptor for the Specific Detection of Polioviruses in Vitro. Journal of Virological Methods. 1993;41:333-40. 